\title{
The test request form: a neglected route for communication between the physician and the clinical chemist?
}

\author{
AR HENDERSON \\ From the Department of Clinical Biochemistry, University Hospital (University of Western Ontario), London, \\ Ontario, Canada
}

SUMMARY The requirements for a clinical biochemistry test request form are reviewed. The interaction between the configuration of the main analysers and the number of individual tests, or profiles, that are ordered using different request form formats were monitored for three-month periods over a three-year period while the main analysers were being "reconfigured" or replaced. Although there was a significant increase in orders for individual tests (compared to profile requests) required on outpatients this did not occur with the inpatient ordering pattern. Instead, the numbers of discretionary tests dropped and more miniprofiles-for example, the electrolyte group, were ordered, although the total number of profiles (per patient day) did not increase because the "electrolyte-urea-creatinine" profile numbers markedly decreased during the period of the study. This shift in ordering patterns was assumed to be due to the faster turnaround of "priority" (emergency) test requests which could, due to improved instrumentation, be analysedF as quickly as individual test requests. Glucose was dropped from the major profile and the numbers of discretionary glucose requests did not increase. It was concluded that, providing this single test can be performed efficiently, there is no need for glucose to be included in test profiles.

The physician may communicate with the hospital department of clinical chemistry by three methods: consulting a member of the laboratory staff, reading the Ward Manual (which might be in the form of a "Kardex" file, a pocket manual or a large, and unwieldy, ring binder) or merely using the test request form. Although the consultation is the most satisfactory method of communication, both it and using the Ward Manual are, or can be, extremely time-consuming for the physician. Therefore by default, the test request form is used, if it can be, for answers to trivial questions (What sample is required?) to more weighty ones (Does the laboratory do this analysis? Is there an assay for a prospective analyte?).

Thus the test request form performs a pivotal role between the physician and the laboratory, and it is indeed surprising that very little appears to have been written about the design of this rather important document. Standard texts either do not refer to the request form at all or mention it only briefly. For

Accepted for publication 7 January 1982 example, the current edition of Todd, et al ${ }^{1}$ refer to the standards of the (US) Joint Commission on Accreditation of Hospitals and the College of American Pathologists which give minimal guidelines for test requisitioning. A few examples of test request forms are given ${ }^{1}$ with a number of comments on the variety of approaches that can be taken. It would seem to be generally agreed, for example, that a test request form might contain some, at least, of the following information about the patient and the specimen (Table 1a). In University Hospital we use all of items 1.1-1.6, 2.1 and 2.2 (Table 1a) on an "Addressograph" plate which is used to imprint the request form. A new plate is created if, for example, there were errors or incorrect data on the plate generated on admission. The bed location is not part of the plate but is contained on the plate frame: a change of patient location then only requires inserting the plate into the current bed-plate frame.

If patient identification data or characteristics are not on some type of imprinter, or the imprinter is not used for some reason, then much less informa- 
Table 1a Summary of information required for patient identification and characteristics and for specimen description

Patient identification

1.1 Full name

1.2 Address

1.3 Unique numbers 1.3.1 Universal: National Insurance (UK), Social Insurance (Canada), Social Security (US) or Insurance Plan Numbers

1.3.2 Local:

Hospital number

1.4 Referring and hospital physician

1.5 Date of admission (if inpatient), or clinic visit (if outpatient)

1.6 Bed number (if inpatient), or clinic type (if outpatient)

Patient characteristics

2.1 Age, or, better, date of birth

2.2 Sex

2.3 Height, weight, build

2.4 Race

2.5 Disease or presenting signs or symptoms

2.6 Other relevant clinical information e.g. known genetic anomalies

Specimen information

3.1 Time of collection

3.2 Nature: blood, urine, etc.

3.3 Preservative/anticoagulants used

3.4 Relevant state of patient, e.g. fasting

tion is usually provided. The policy of the Department of Clinical Biochemistry is to decline to accept, absolutely, any specimen for analysis that lacks the minimal requirement of patient name, chart number and location (this is stated on the request form). Needless to say, a specimen tube lacking any means of identification will not, under any circumstances, be accepted for analysis. It must be obvious that for many (?most) analytical requests the complete list of patient data contained in Table 1a is quite unnecessary, and that a minimal requirement, such as the one we use, is usually more than sufficient. The only constraint is that patient identification, and location, should be defined unambiguously.

The advent of routine therapeutic drug monitoring has gone some way to increasing these minimal requirements for patient and specimen data. A tentative standard ${ }^{2-4}$ for therapeutic drug monitoring and overdose toxicology requisition forms has recently been issued by the National Committee for Clinical Laboratory Standards (NCCLS) in the United States. Our own requirements in this regard partially echo the NCCLS recommendation (Table $1 b)$, and were derived by consensus between the Department of Clinical Biochemistry, the Clinical Pharmacology Service, and the staff of the Emergency Department and the Intensive Care Unit in University Hospital together with a consideration of opinions expressed in published reports. ${ }^{5}$

Obviously, the expanding range of assays offered by a clinical chemistry department also influences the contents of the test request form, as the example of therapeutic drug monitoring quoted above makes clear; but the provision of more mundane services, such as electrolytes, also requires close attention. This first became apparent to us soon after University Hospital opened in 1972. Little additional provision was made, initially, for the demands of the STAT - that is, the Priority Test service except for the assay of serum glucose, calcium, sodium and potassium (Table 2). The introduction of better telephone procedures ${ }^{6}$ and the priority test request form ${ }^{7}$ alleviated this situation for a short while, but it was evident that the analyser configurations had to be modified. It will be appreciated that a proposed capital expenditure of Can $\$ 250000$ ( $£ 137000)$ on new equipment takes considerable time to arrange, so that a number of "jury" arrangements were made in the interim period (Table 2). For example, we noticed a large number of priority SMA-6.1 (electrolytes, urea and creatinine) profiles coupled to glucose requests. These required (up to early 1979), splitting of the sample (one to the SMA-6.1 and the other to the glucose analyser, both analysers were effectively run on a $24 \mathrm{~h}$-basis) for accelerated analysis on these two routine instruments. This arrangement was unsatisfactory for a number of reasons so we reconfigured the SMA-6.1, by adding a glucose channel (the new SMA-7.2, see Table 2), and we changed the test request form (Figure 1.ii). Like the SMA-6.1 before it, the SMA-7.2 was kept running virtually 24 -hours each day. ${ }^{*}$

It may seem strange to British clinical chemists, that the workload of a 400-bed hospital should create such problems. Actually the work load in a Canadian teaching hospital is, per inpatient day, about eightfold greater for creatinine and potassium analyses, and up to twentyfold greater for glucose analyses, than for British teaching hospitals ${ }^{8}$ and we recently pointed out that total workloads of a 400 bed Canadian hospital approach that for a 2000-bed British hospital. ${ }^{9}$

While the analytical instrumentation systems were evolving, and the test request form was being modified, a study was conducted, over a three-year period, on the influence of the test groups in the test request form on the demands for some of the more commonly requested analytes. The results of this study are reported in the next section and following

\footnotetext{
*The complementary parts of our original SMA (SMA-7.1 or SMA-6.2) were only run during the day-shift when there were sufficient staff to operate both modules. Therefore, a request for a "full" SMA analysis necessitated a split sample with consequent delay in issuing half of the results. By contrast, analysis of the new "admission profile" can easily be accomplished by one technologist using the SMA-II. There is minimal delay in issuing these results as this analyser is operated in batch mode morning, afternoon and evening, seven days a week.
} 
that, descriptions of our current test request form are given together with associated reporting forms, and the revised priority test request form. ${ }^{7}$

\section{The influence of the test request form on test demands}

\section{METHODS}

\section{Statistical methods}

The Mann-Whitney U test was used to test for the significance of groups of monthly data between different years. ${ }^{10}$

\section{Duration of study}

Data (described below) were collected over the periods of September to November, inclusive, during 1978, 1979 and 1980.

\section{Test numbers}

The number of tests (both single and profile) requested, using the then current test request form (fig. 1) were recorded over the period of study by using the Test Statistics package (inpatient and outpatient requests are collected separately) in the Department of Clinical Biochemistry's computer system. As well as the Grouped Analysis (Blood) section (Fig. 1) there were Single Analysis (Blood) sections on both the 1978 and 1979 forms although these are not shown in Fig. 1.
Table $1 \mathrm{~b}$ Additional information required for therapeutic drug monitoring and drug screening requests

Dosage information

4.1 Drug (with generic name) being used. Formulation where this is relevant.

4.2 Time at which last dose was given

4.3 Route of administration

4.4 Dose: loading and maintenance

4.5 Duration of therapy

4.6 Other drugs being used

Reason for therapeutic drug monitoring

5.1 "At risk" state: Drug interaction; disease of gut, kidney, liver, heart or thyroid; hypoalbuminaemia pregnancy and lactation; age if considered relevant

5.2 Therapy considered: inadequate, adequate or a cause of toxicity

5.3 Compliance considered: adequate or inadequate

Reason for drug screening request

6.1 Patient state: such as inebriated, hallucinating, agitated excited, disoriented, drowsy, arousable with difficulty, and so on

6.2 Colateral findings: constricted or dilated pupils, needle

6.3 Drugs or poisons suspected marks, tachycardia or arrhythmias

6.4 Drugs administered in hospita

6.5 Sample provided

\section{Inpatient activity}

This was recorded from hospital and Hospital Medical Records Institute (HMRI) records. (theo HMRI collects data on patient activity from all Ontario hospitals as part of a record of hospitale

Table 2 Analyser configurations for major serum analytes

\begin{tabular}{|c|c|c|c|}
\hline \multirow{2}{*}{$\frac{\text { Period }}{1972-78}$} & \multicolumn{2}{|c|}{ Routine profile system } & \multirow{2}{*}{$\begin{array}{l}\text { Priority }(\mathrm{STAT}) \text { systems } \\
\mathrm{Na}^{+} \text {and } \mathrm{K}^{+}: \text {IL } 343 \\
\text { Glucose: } \mathrm{AA}-2^{*} \\
\text { Creatinine and urea: start up SMA- } 6.1 \mathrm{Ca}^{2+}: \text { AAS }\end{array}$} \\
\hline & $\begin{array}{l}\text { SMA-6.1: } \\
\text { SMA-7.1: }\end{array}$ & $\begin{array}{l}\text { electrolytes, urea and creatinine } \\
\text { total protein, albumin, calcium 'phosphate', } \\
\text { total bilirubin, urate and glucose }\end{array}$ & \\
\hline 1979 & $\begin{array}{l}\text { SMA-7.2: } \\
\text { SMA-6.2: }\end{array}$ & $\begin{array}{l}\text { electrolytes, urea, creatinine and glucose } \\
\text { total protein, albumin, calcium 'phosphate', } \\
\text { total bilirubin, and urate }\end{array}$ & $\begin{array}{l}\text { Discretionary: Beckman Glucose Analyzer and } \\
\text { IL } 343 \\
\text { Profile: Start up SMA-7.2† }\end{array}$ \\
\hline \multirow[t]{2}{*}{1980} & SMA II: & $\begin{array}{l}\text { electrolytes, urea, creatinine, total protein, } \\
\text { albumin, calcium, 'phosphate', total bilirubin } \\
\text { and urate }\end{array}$ & $\begin{array}{l}\text { Discretionary/Profile: Beckman ASTRA-8- } \\
\text { electrolytes, urea, creatinine and glucose }\end{array}$ \\
\hline & Note: & Glucose dropped completely from profiles & $\begin{array}{l}\text { Discretionary glucose: AA- } 2 \text { when requested } \\
\text { beyond } 1 \text { or } 2 \mathrm{~h} \text {, depending on staffing level and } \\
\text { demand backlog }\end{array}$ \\
\hline
\end{tabular}

Electrolytes $=\mathrm{Na}^{+}, \mathrm{K}^{+}, \mathrm{HCO}^{-}, \mathrm{Cl}^{-}$

SMA = Sequential Multiple Analyzer. SMA-6.1 is equivalent to the Technicon SMA 6/60 but the other SMA configurations (SMA-6.2, SMA-7.1 and SMA-7.2) are laboratory reconfigurations of the SMA 18/60 system (Technicon Instrument Corporation, Tarrytown, New York).

SMA II = SMA 12/90 (Computer Controlled Multichannel Biomedical Analyzer; Technicon).

IL 343 = Instrumentation Laboratories Inc, Lexington, Massachusetts.

AA-2 = AutoAnalyzer II continuous flow system (Technicon).

AAS = Atomic absorption spectrometry.

Beckman $=$ Beckman Instruments Inc., Fullerton, California.

ASTRA-8 = Automated Stat-Routine Analyzer System, 8-channel (Beckman).

*After 1977, glucose was analysed by Beckman Glucose-2 Analyzer because of repeated complaints about our prolonged turnaround times.

†After continual complaints about prolonged turnaround times for urea, creatinine, chloride and bicarbonate, we installed the individual Beckman Analyzers for these analytes. 
(i)

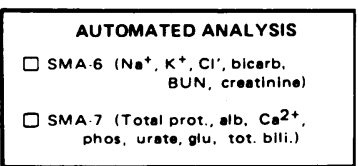

(ii)

\begin{tabular}{|c|c|}
\hline & ROUPED ANALYSIS (BLOOD) \\
\hline$\square$ & $\mathrm{Na}^{+}$and $\mathrm{K}^{+}$only \\
\hline & $\begin{array}{l}\text { Electrolytes: } \mathrm{Na}^{+}, \mathrm{K}^{+}, \mathrm{Cl}^{+} \text {and } \\
\text { bicarbonate }\end{array}$ \\
\hline$\square$ & Electrolytes, BUN and creatinine \\
\hline & $\begin{array}{l}\text { Electrolytes, BUN, creatinine } \\
\text { and glucose }\end{array}$ \\
\hline & $\begin{array}{l}\text { Electrolytes, BUN, creatinine, } \\
\text { glucose, } \mathrm{Ca}^{2}{ }^{2} \text { and albumin }\end{array}$ \\
\hline & $\begin{array}{l}\text { Admiss:on Profile: Electrolytes, } \\
\text { BUN, creatinine, glucose, Ca } \\
\text { inorg. phos., total protein. } \\
\text { albumin, total bilirubin } \\
\text { and urate }\end{array}$ \\
\hline $\begin{array}{l}\text { NOTE } \\
\text { THIS } \\
\text { AVAI }\end{array}$ & $\begin{array}{l}\text { E: ADMISSION PROFILE IS NOT } \\
\text { ILABLE AS A PRIORITY TEST }\end{array}$ \\
\hline
\end{tabular}

(iii)

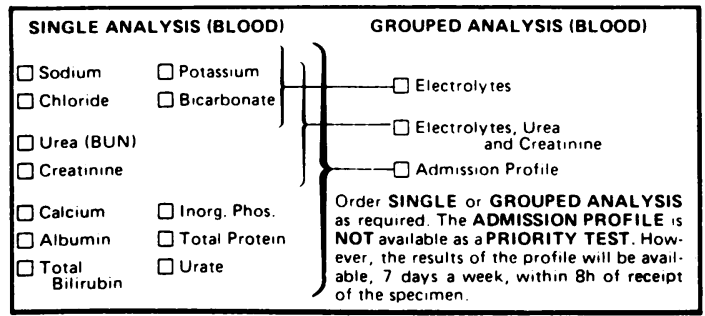

Fig. 1 The grouped (multichannel) analysis section of the test request forms used in 1978, 1979 and 1980. (i) the 1978 form. In the Single Analysis section (not shown) are listed, individually, glucose, sodium, potassium, urea, creatinine, albumin, total protein and calcium. (ii) the 1979 form in which there are more subdivisions of the available 13 channels (see Table 2). As with the 1978 form the Single Analysis section is not shown, but it was identical to the earlier form. (iii) the 1980 form in which the individual tests of Grouped Analysis could be ordered individually or in combination as required.

statistics). Primary diagnosis and diagnostic or therapeutic procedures were coded, and entered, by the hospital's Medical Records Department, into the HMRI computer system following inpatient discharge, using the International Classification of Disease listings. ${ }^{11} 12$ These records can subsequently be recalled retrospectively from the HMRI computerresident files. Eleven primary diagnostic groups (see Table $3 a$ ) and nine procedures (see Table $3 b$ ) were chosen as representing the spectrum of inpatient activity. Inpatient bed occupancy was obtained from the hospital's monthly Medical Records summary.

\section{Outpatient activity}

HMRI records are not kept on outpatients so that numbers of clinical visits were used as a measure of
Table 3a Primary diagnostic groups representative of inpatient activity

\begin{tabular}{|c|c|c|c|c|}
\hline $\begin{array}{l}\text { Primary } \\
\text { diagnosis }{ }^{11}\end{array}$ & 1978 & 1979 & 1980 & $\begin{array}{l}\text { Trend with years, } \\
\text { if statistically } \\
\text { different }\end{array}$ \\
\hline $\begin{array}{l}\text { Diabetes mellitus, } \\
\text { uncomplicated }\end{array}$ & 60 & 33 & 17 & $\downarrow$ \\
\hline $\begin{array}{l}\text { Diabetes mellitus, } \\
\text { with acidosis or } \\
\text { coma }\end{array}$ & 8 & 30 & 50 & $\uparrow$ \\
\hline $\begin{array}{l}\text { Acute myocardial } \\
\text { infarction }\end{array}$ & 48 & 28 & 39 & none \\
\hline $\begin{array}{l}\text { Chronic liver } \\
\text { disease and } \\
\text { cirrhosis }\end{array}$ & 37 & 54 & 37 & none \\
\hline Viral hepatitis & 3 & 2 & 2 & none \\
\hline $\begin{array}{l}\text { Nephrotic } \\
\text { syndrome }\end{array}$ & 1 & 2 & 1 & none \\
\hline $\begin{array}{l}\text { Calculus of kidney } \\
\text { or ureter }\end{array}$ & 27 & 20 & 18 & none \\
\hline Kidney donor & 1 & 3 & 2 & none \\
\hline $\begin{array}{l}\text { Multiple } \\
\text { sclerosis }\end{array}$ & 21 & 32 & $3 \overline{1}$ & none \\
\hline Epilepsy & 48 & 74 & 59 & $\uparrow$ \\
\hline $\begin{array}{r}\text { Subarachnoid } \\
\text { haemorrage }\end{array}$ & 37 & 43 & 41 & none \\
\hline
\end{tabular}

Table 3b Medical and surgical procedures representative of inpatient activity

\begin{tabular}{|c|c|c|c|c|}
\hline Procedures $^{12}$ & 1978 & 1979 & 1980 & $\begin{array}{l}\text { Trend with years, } \\
\text { if statistically } \\
\text { different }\end{array}$ \\
\hline $\begin{array}{l}\text { Percutaneous } \\
\text { biopsy of liver }\end{array}$ & 37 & 21 & 23 & none \\
\hline $\begin{array}{l}\text { Peritoneal dialysis } \\
\text { Haemodialysis }\end{array}$ & $\begin{array}{l}11 \\
13\end{array}$ & $\begin{array}{r}2 \\
21\end{array}$ & $\begin{array}{r}2 \\
20\end{array}$ & \\
\hline $\begin{array}{l}\text { Haemodialysis } \\
\text { Kidney transplant }\end{array}$ & $\begin{array}{r}13 \\
8\end{array}$ & $\begin{array}{r}21 \\
7\end{array}$ & $\begin{array}{r}20 \\
8\end{array}$ & none \\
\hline $\begin{array}{l}\text { Transurethral } \\
\text { prostatectomy }\end{array}$ & 47 & 25 & 24 & $\downarrow$ \\
\hline $\begin{array}{l}\text { Aorto-coronary } \\
\text { bypass }\end{array}$ & 37 & 34 & 47 & none \\
\hline $\begin{array}{l}\text { Heart valve } \\
\text { replacement }\end{array}$ & 11 & 10 & 11 & none \\
\hline Cholecystectomy & 43 & 36 & 48 & none \\
\hline $\begin{array}{l}\text { Repair of cerebral } \\
\text { aneurysm }\end{array}$ & 31 & 42 & 54 & $\uparrow$ \\
\hline
\end{tabular}

outpatient activity; these also were obtained from the Medical Records summary report.

\section{RESULTS}

\section{Inpatient requests}

Inpatient activity is listed in Tables 3 ( $a$ and b). Only some of these activities show a statistically significant $(p \leqslant 0.05)$ increase (or decrease) with time; these tests are indicated in the Tables. It should be noted that as the number of admissions with uncomplicated diabetes mellitus decreased, those admitted in acidosis, or coma, increased. In general, however, the overall spectrum of inpatient activity, as it affects the Department of Clinical Biochemistry, appeared fairly stable during the 
Table 4 Test numbers for some discretionary tests and for profiles of major serum analytes requested on inpatients in September, October and November of three consecutive years

\begin{tabular}{|c|c|c|c|}
\hline Test(s) & $1978 \dagger$ & $1979+$ & $1980 \dagger$ \\
\hline Discretionary glucose & 5783 & 4807 & 6050 \\
\hline Discretionary $\mathrm{K}^{+}$ & 3324 & 435 & 483 \\
\hline \multicolumn{4}{|l|}{ Profilę: } \\
\hline $\begin{array}{l}\mathrm{Na}^{+}+\mathrm{K}^{+} \\
\text {Electrolytes }\end{array}$ & Not available on form & $\begin{array}{r}95 \\
95\end{array}$ & $\begin{array}{r}432 \\
4655\end{array}$ \\
\hline $\begin{array}{l}\text { Electrolytes } \\
\text { Electrolytes, urea and creatinine }\end{array}$ & Not available on form & & 2655 \\
\hline $\begin{array}{l}\text { Electrolytes, urea and creatinine } \\
\text { SMA-7. }{ }^{*}\end{array}$ & $\begin{array}{l}3173 \\
1456\end{array}$ & $1^{1731}$ & 1877 \\
\hline $\begin{array}{l}\text { Electrolytes, urea, creatinine glucose } \\
\text { SMA } 6.2^{*}\end{array}$ & Not available on form & $\begin{array}{r}954 \\
1525\end{array}$ & - \\
\hline SMA-6.1* + SMA-7.1* & 2795 & - & - \\
\hline $\begin{array}{l}\text { Admission profile including glucose } \\
\text { (SMA-6.2* }+ \text { SMA-7.2*) }\end{array}$ & - & 4110 & - \\
\hline Admission Profile (SMA II*) & - & - & 5002 \\
\hline Total for all profiles & 9424 & 10150 & 9966 \\
\hline Total for discretionary $\mathrm{K}^{+}, \mathrm{Na}^{+}+\mathrm{K}^{+}$, and electrolyes & 3324 & 2265 & 3570 \\
\hline
\end{tabular}

${ }^{*}$ Refer to Table 2 for instrument configurations.

†Patient-days $1978 \quad 30941$

$$
\begin{aligned}
& 197931095 \\
& 1980 \quad 33 \quad 151
\end{aligned}
$$

[patient-days in 1980 period was significantly greater $(\mathrm{p}<0 \cdot 05)$ than during the 1978 or 1979 periods].

period of study although bed occupancy rose from $89 \%$ (1978) to $91 \%$ (1980); the average length of stay varied between 11.2 and 11.5 days.
The number of test requests, involving multichannel analyzers, are tabulated in Table 4 together with the numbers of discretionary glucose and potassium

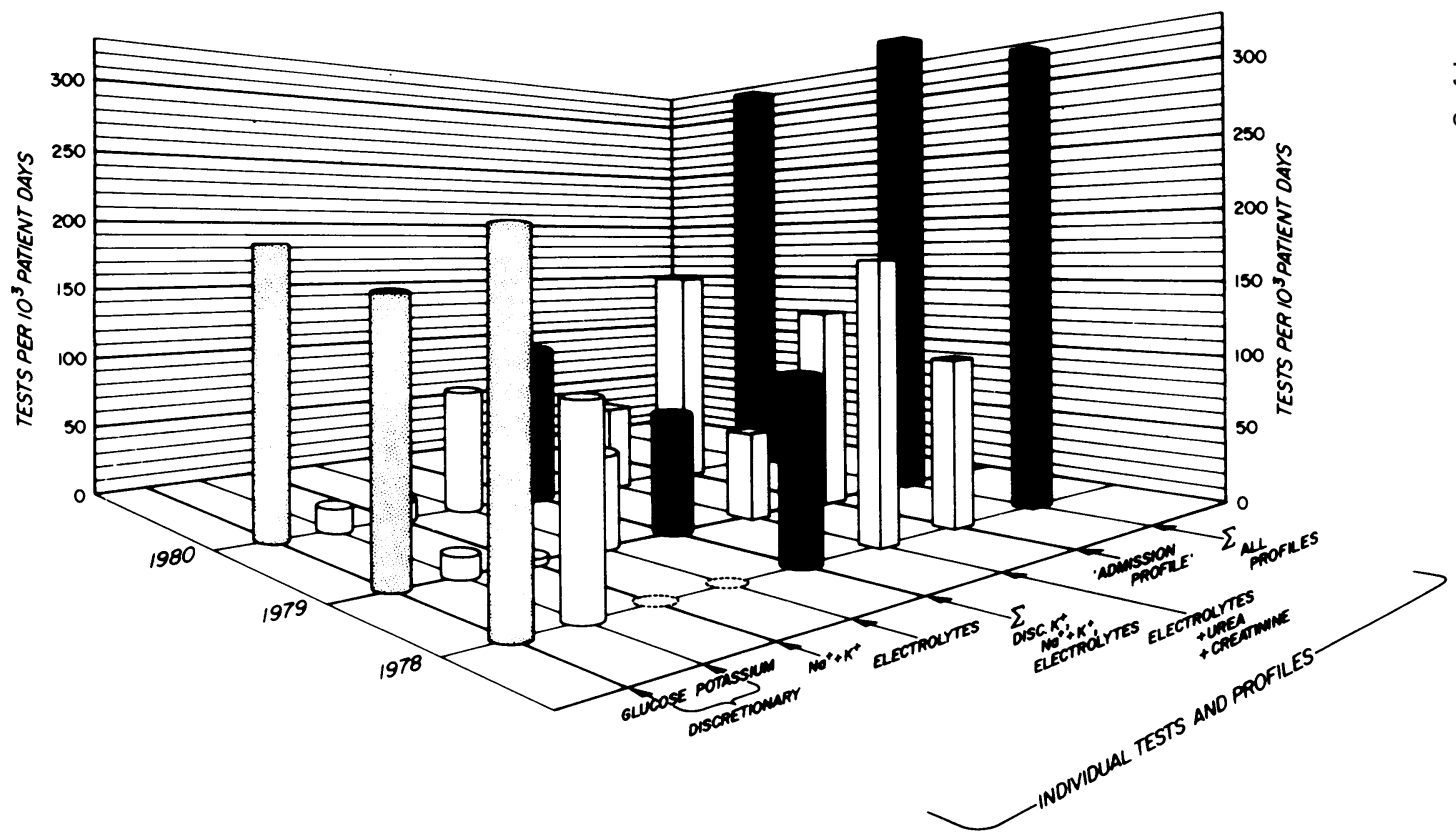

Fig. 2 Inpatient data for some discretionary and profile tests requested in the period 1978 to 1980 . Test numbers are expressed per 1000 inpatient days derived from the basic data listed in Table 4. Discretionary glucose requests are represented by shaded circular rods. Open circular rods indicate discretionary potassium requests, "Na ${ }^{+}+\mathrm{K}^{+\prime "}$ and "electrolyte" profile requests. The sum of these three test categories are represented by the dark circular rods. The profiles "electrolytes + urea + creatinine" and the "admission profile" (defined for the different periods within Table 2) are represented by open square rods and the sum of all profiles (including all profiles listed in Table 4) are represented by dark square rods. 
requests.* It will be noted that although the number of available profiles increased there was not an overall increase in the total number of profiles ordered.

However, because occupancy increased significantly in 1980 it is essential to correct all data for this factor. Accordingly, in Fig. 2 the test figures have been expressed as tests per 1000 patient days. This diagram shows a number of interesting trends. The number of discretionary glucose requests in 1978 and 1980 are not significantly different $(p>$ 0.05 ), yet glucose was dropped from all profiles in 1980 and was then only available as a discretionary request. There were also likely to be increased demands for glucose estimations (Table 3a) in 1980, yet demand had obviously plateaued. Discretionary potassium was commonly requested in 1978 but the request numbers dropped by 1980: the sum of discretionary potassium, $\mathrm{Na}^{+}+\mathrm{K}^{+}$, and electrolyte requests in 1980 were not significantly different ( $p$ $>0.05$ ) from the number of discretionary potassium requests in 1978 . Finally, the total number of profiles requested (including miniprofiles such as electrolytes) did not change significantly $(p>0.05)$ from 1978 to 1980 . Figure 2 therefore shows a clear shift to the right-that is, a move to more comprehensive profile requests. It is noteworthy that in the same period the laboratory became capable of issuing priority results with a very short turnaround time, due to the capabilities of the 7-channel Beckman analyzer (Table 2) and, as previously noted, the "admission profile" results were issued during 1980 as a complete set much more rapidly than when the original SMA system was in use (Table 2). Apart from glucose and potassium, single test requests were ordered less frequently than profiles: the ratio single tests : profiles for in-patients was about 3:50. This ratio remained unchanged during the period of study.

\section{Outpatient requests}

Outpatient visits remained stable during the study, averaging about 7000 each month. While the number of profile requests did not change, there was a significant $(p<0.05)$ increase in the number of single tests requested. For example, single requests

\footnotetext{
*The term "discretionary" is used to mean the selection of a single test instead of that single test ordered together with some others. Thus, the four tests ('electrolytes') might be requested when only the potassium level is actually required. In the more general sense, of course, all tests, whether single or profile, are discretionary; that is, they are ordered by the physician. These types of tests must be differentiated from routine profiles which are done as a hospital policy: ${ }^{13}$ University Hospital does not have such a policy although many hospitals do.
}

for calcium, creatinine and urate increased by $50 \%$ and albumin by $31 \%$. To place this increase in perspective, it should be noted that outpatient work is about $25 \%$ of the inpatient work load.

\section{DISCUSSION OF STUDY}

It was our intention, when revising the test request form, to encourage a move away from profile requests without, of course, removing that option entirely. It is evident that while we did not achieve this for the inpatient work load a change did occur with outpatient requests. The reason for this difference is likely due to the different ordering procedures used. In the Outpatient Clinic the physician usually writes the test requests directly onto the test request form and then writes these orders in the patient record: with inpatients the orders are initially entered in the patient record and are subsequently transcribed on to a request form by the ward clerkess. Therefore with the latter group of requests, the form will have less influence on ordering patterns although we are not certain, nonetheless, that there many not be a long-term effect.

Paradoxically, we appear to have caused a shift away from discretionary potassium requests, on inpatients, to miniprofiles such as the electrolyte group (Figure 2). One reason for this, as previously suggested, is our increased priority test capability (see Table 2), particularly in terms of very rapid turnaround times, that is receiving increased use. Previously the ratio of priority : routine for electrolytes was $0.44,{ }^{14}$ now (1981) that ratio is 0.74 . The electrolyte-urea-creatinine profile ratio was $0.73,{ }^{14}$ it is now 0.93 . These are examples of the dictum: "quicker assays-more requests." Thus the influence of superior instrumentation has nullified, for inpatient requests, the influence of a change in the test request form format.

\section{Decription of current test request form}

When the hospital opened in 1972, Clinical Biochemistry provided four multipart preprinted forms for test ordering with one of the parts being used to report results. In 1977 a data management (computer) system was installed in Clinical Biochemistry and a test request form was designed by "blending" the request sections of the earlier Forms. Result forms were unnecessary as the computer generated result reports. The test request form has since undergone a number of subsequent revisions - for example, the demands of drug screening and therapeutic drug monitoring necessitated using the back of the form; but the basic format has been retained whenever possible. The form is printed in the hospital's print shop in quantities of 
1. Requents for PAIORITY TESTS must be eccompanied by the relevent form

2. Minimum blood volumes (which are edditive) are indicated first after each test, with the colour of the vecutainer eccond. Thus $10 \mathrm{f}$ moens $10 \mathrm{ml}$ of blood in a red top wbe. Other tube verpes ere eithor given in full or as G (green) L l levender) or DB (derk blual. Whan eithor/both blood volume
is edded, then consult Laboratory Manual

3. Minimum urine volumes (ml) are given thus Pre op 112 or $124 \mathrm{~h}$ i for a 24 hour collection Special conditions are marked" consult Leboratory Menual CLINICAL INFORMATION

\section{INSTR}

Plose moke NAME CHART NUMBER and LOCATION Iogidio \begin{tabular}{l:l} 
INSTRUCTIONS FOR COLLECTION OF SPECIMENS \\
Time & Other Instructions \\
\hline
\end{tabular}

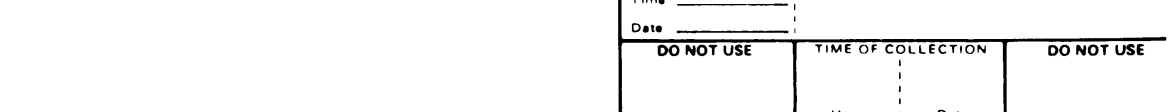

SINGLE ANALYSIS (BLOOO) , GROUPED ANALYSIS (BLOOO)

DSodium ANALYSIS (BLOOD

$\square$ Chioride

DUres (BUN)

$\square$ Creatinine

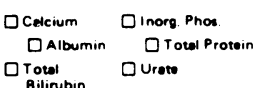

Bilinubin

\section{a)}

DSerum Protein Electrophoresis (2R)

$D$ Meonesium (5R)

$\square$ Zinc (50B) Q Copper (50B)

D Lectots (2Groy) OAmmonia (3G .

\section{GLUCOSE and GLUCOSE
TOLERANCES (BLOOD)}

DGlucow, fating (2R)

$\square$ Glucose. rendom (28)

G Glucase. 2h PC (2R)

$\square$

DGT, 3h

DGTT 4h | exch specimen

DGTT. $5 \mathrm{~h}$

口

LIPIO ANALYSIS ISRI

DCholesterol QTriglyceride

$\square$ Lipoprotein Electrophoresis

口

SPINAL FLUID
DProtein

$\square$ Protein Electrophoresis

$\square$

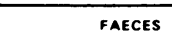

DF exced Occult Blood (special peck)

D F excal fat lore weighed can

D

840110409166009811 ReV

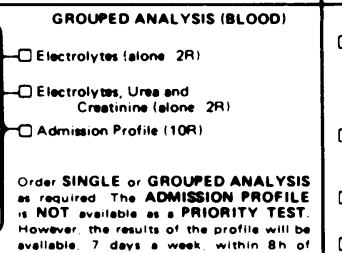

ovolloble 7 devis o weok within 8 h of recolpt of the epecimen

ROUTINE URINALYSIS

$\square$ first morning voiding Dandom

DPro oo (12)

QRoutine (includes microscopy) (12

\section{URINE/FLUID CHEMISTRY}

DTimad Colloction

START TIme _Date

END Time Oate -

$\square$ Non Urine Trpe Istate)

DOsmolality

DProtein

$\triangle$ Protein Electrophoresis

$\square$ Sodium $\square$ Potessium

$\square$ Chloride

$\square$ Creatinine

QCreatinine Clearance Send urine

$\square$ Phosphate $\square$ Calcium

Qurate aurea

DMognesium

$\square$ Copper :

DZinc (•)

$\square$ Calculus Analysis

$\square$ Urobilinopen

D Porphyrin Screen

$\square$

0

$\square$

\begin{tabular}{|c|c|}
\hline EN2YMES & HORMONES (BLOOO) \\
\hline$\square$ Cerdiac Profile & $\square$ Cortisol (0900h) (2G) \\
\hline $\begin{array}{l}\square \text { L wer Profile } \\
\text { (transemineves AP } \\
\text { Gamme GT) (IOR) }\end{array}$ & $\begin{array}{l}\square \text { Testocterone (5R) } \\
\text { DPropenterone (5R) }\end{array}$ \\
\hline
\end{tabular}

Pencreatic Profile

Pencreatic Profile
(Amyilese. Lipene) (5P) $\square$ Alo Transeminase (PT) (2R)

$\square$ Asp Tronseminase $(O T)$ (2R) $\square$ Creatine $K$ inase $(C K)$ (5R)

$\square C K$ and isoenzymes (5R)

$\square$ Lactate Dehydropenme (LD) I2R

$\square L O$ and isoenzymes (5R)

$\square$ Alkaline Phosphatese (AP) (2R)

CAP and isoenzymes (5R)

DAmylase I2R) QLipase (2R

口Amylase (Urinel (5)

$\square$ Amylase Creatinine Clearonce
Ratio isend Urine and Aloodi

$\square$ Acid P osinhatase Prostatic (5A)

DCholinesterase Serum I2R!

CCholinesterase Phenotyde i5Ri

$D$ Aldolase $2 \mathrm{~A}$.

$\square$

\section{THERAPEUTIC DRUG}

$\triangle$ Mark here and enter required

drug(s) and details of dosage

TOXICOLOGY IBLOOO\& URINEI

Motals

DB Lear: 20l … L Lead $24 n$.

DB Mercury 101 EUNercury

D

Drua (blood) lone or all 5R)

$\square$ Ethanol $\square$

DBromide

DUTHER DRUGS

Mark here, and enter on other side
if relevant to vour requirements DFSH (2R) DLH(2R)
DGamma givcomyl transoeptidere
(Gamma.GTi (2R)

DSalicylate $\square$ Acetaminophen
口 17 B. Ontradiol I5R

DOmirone (5A)

$\square$ Androstenedione (4R)

$\square$ insulin (2R)

$\square$ Growth Hormone (2R) $\square$ Corticotropin

$\square$ Thyrotropin (TSH) (2R)

$\square$ Prolactin (2R) $\square$ HCG (4R)

Denin Activity $17 L$.

$D$ Gestrin (2R)

DPTH $(10 \mathrm{O})$

$\square$ Calcitonin (10G*)

$\square$ Aldosterone (1OR) $\square$

\section{HORMONE (URINE)}

D5. HIAA Screen $24 \mathrm{~h}$ :

DFree Cortisol (24h)

017 Ketosteroids (24h)

D 17 Ketooenic Steroids 124h

C VMA $24 h$.)

DF ree Catecholemines (24h.

$O$ Metonephrines (24h *)

0 Total Oestrogens
(non preg) (24h)

$\square$ Uestriol |pregi (24h)

$\square$

DPregnanetriol (24h)

DAldosterone :24h

0

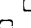

o

REOUEST RE JEC TED
$\square$ Incomplete Patient ID rodo
$\square$ IU not on file contact us
$\square$ No specimen received
$\square$ Specimen not identified
$\square$ improper specimen
$\square$ incomplete information

Fig. 3 The current (1981) Clinical

Biochemistry requisition form. Requests for Therapeutic Drug Monitoring and Toxicology are directed to the reverse side of the form (see Fig. 4). Dimensions are 28 $\times 21.5 \mathrm{~cm}$.
50000 which last about six months. This short turnover allows timely revisions to be made such as the addition of new tests-a fairly common occurrence.

The layout of the form is clear (Figs. 3, 4). The most commonly requested tests occupy the middle portion of the form and the individual sections are clearly labelled. The request boxes are "staggered" to make best use of available space and it prevents the careless marking of one box "overflowing" into adjacent test boxes. Sufficient room has been left on the form to allow addition to each section when that becomes necessary. For example, we will be adding $\mathrm{S}$-Aluminum and U-Aluminum to the toxicology section at the time of the next printing.

The Addressograph imprint is placed in the top right-hand corner (Fig. 3) and space is provided for clinical information, instructions for specimen collection including proposed and actual time of collec- 
QUALITATIVE DRUG SCREENING

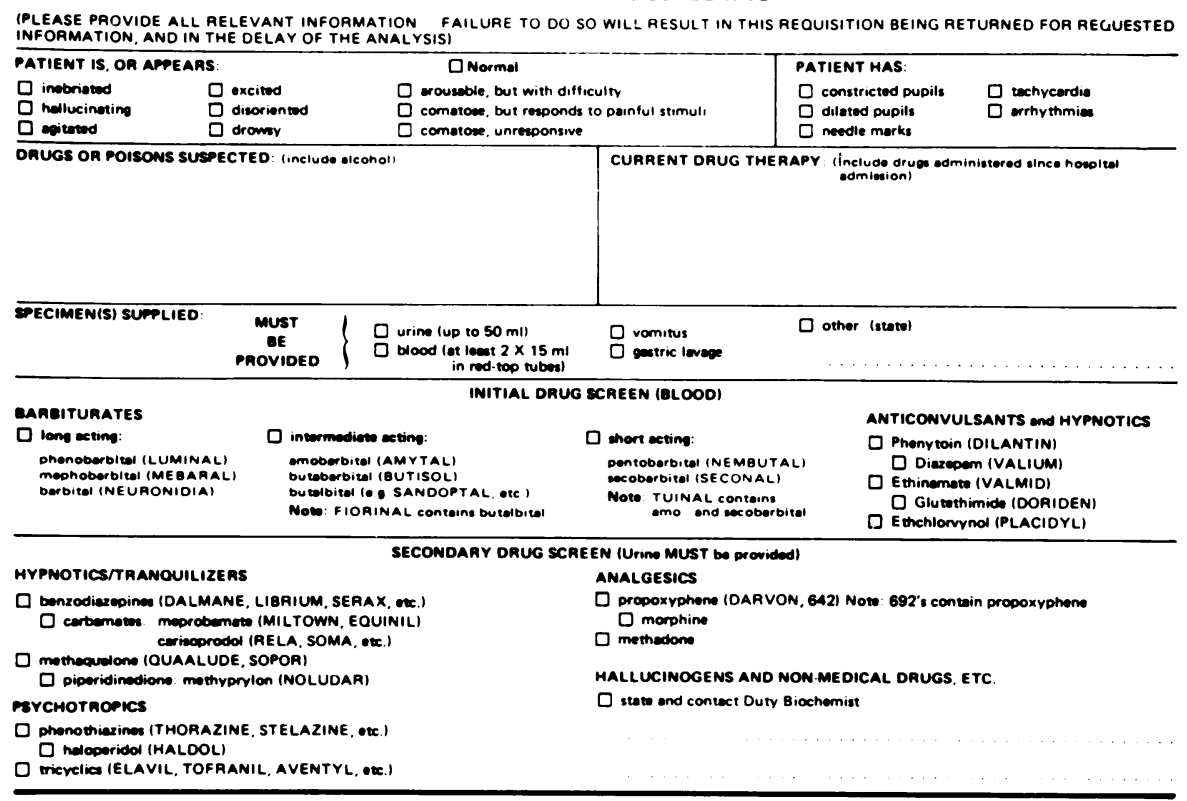

THERAPEUTIC DRUG MONITORING

IPLEASE PROVIDE ALL AELEVANT INFORMATION - FAILURE TO DO SO WILL RESULT IN THIS REQUISITION BEING RETURNED FOR REOUESTED (PLEASE PROVIDE ALL RELEVANT INFORMATION - FAIL
INFORMATION. AND IN THE DELAY OF THE ANALYSIS)

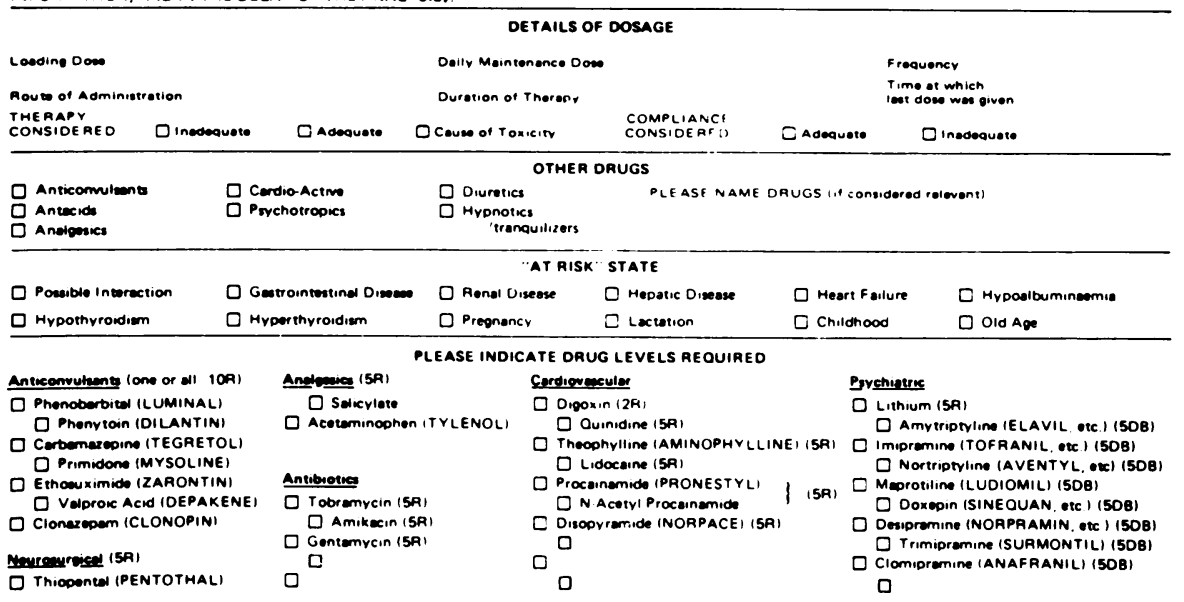

Fig. 4 The Qualitative Drug Screening and Toxicology Drug Monitoring sections of the current (1981) requisition form. tion and, on the outer right hand edge, laboratory time stamp. The inner Do Not Use box is for entering the computer-generated laboratory sample number. In the top left-hand zone are notes on usage. The user is admonished (Note 1 and Grouped analysis) to observe the rules regarding priority tests, and general guidance is given (notes 2 and 3 ) regarding the type and volume of sample required for all analytes. For example, under Grouped Analysis (Blood) $2 \mathrm{ml}$ of blood in a red-topped Vacutainer tube (that is, serum) is required for electrolyte analysis. At the bottom right hand corner is a Request Rejected box. This is used most commonly when incomplete information has been provided to the laboratory with regard to Therapeutic Drug Monitoring or overdose toxicology requests. It will be seen that both these sections are referenced to the back of the form (Fig. 4). Qualitative drug screening is based on a comprehensive, commercially-available, thin-layer chromatography system and this accounts for the two drug screens. The initial Drug Screen (Blood) detects the barbitu- 
rate group and a number of anticonvulsants and hypnotics (the acid and neutral drugs extracted at pH 4.5); the Secondary Drug Screen (Urine) is more comprehensive (the basic and neutral drugs extracted at $\mathrm{pH} 9$ ). In either case the physician can communicate clearly with the laboratory: if the drug is not listed it will be evident that a dialogue with the laboratory (in the person of the Duty Biochemist) should follow.

The information requested in the Therapeutic Drug Monitoring section is demanding of the requestor. This is intentional. The potential consequences of inappropriate sampling for drug levels, in relation to the time of the last dose, are so serious that the information-" "time at which last dose was given"-is always demanded, unless the patient is on chronic administration of the drug(s) as, for example, with anticonvulsants. In practice, we have found that the majority ( $>95 \%$ ) of requestors provide the necessary information; an average of one incomplete test request form is sent back every day for the provision of this information. In this connection, a recent survey in the United States concluded $^{15}{ }^{16}$ that "... request/report forms are not optimally configured to facilitate effective therapeutic drug monitoring."

The factors that should be considered in designing a test request form are listed in Table 5, a list that has grown over the eight years since University Hospital opened due to the interest of many hospital staff in the problem of communicating effectively with the laboratory. We have applied some of these concepts to the redesign of the priority test request form. ${ }^{7}$ Currently, a priority test is simply ordered by ticking the appropriate time delay box for the required test (Fig. 5). This modification has reduced, almost totally, the requesting of "illegal" priority tests. Previously, unlisted tests could be, and sometimes were, written in the blank spaces of the earlier priority test request form.?

When the Clinical Biochemistry Department's computer is not working, due either to maintenance work or component failure, a manual back-up reporting system is used. Often this back-up is included as part of the main test request form. For example, Grams ${ }^{17}$ described the use of such a form. However, such an arrangement wastes a substantial amount of space on the form that is only required for less than $0.5 \%$ of the time. This appears to be a poor trade-off. At University Hospital we take the view that a separate set of forms is a more realistic solution to this problem. The Manual Report-A (Fig. 6) covers the main group of requests and a blank Manual Report-B (Fig. 7) allows manual recording for any other group of tests. When the computer is down, we use a separate sample number system, printed on special bright red tape, and space is required on the forms for these stand-by numbers. When computer function is restored, these completed forms (the original is retained in the laboratory and photocopies are sent to the clinical units) are used by the laboratory staff to "back-enter" results on a patient-by-patient basis.

\section{Discussion}

We introduced the blood volume information on the form about one year ago. Since then there has been a marked decrease in the amount of blood that we receive for drug and endocrine assays. For example, it was previously common to receive three or four 10 $\mathrm{ml}$ tubes of blood for a group of anticonvulsant assays whereas now (Fig. 4) only a single $10 \mathrm{ml}$ tube is sent to us. The need for special conditions during sample collection, indicated by an asterisk on the form, has also proven useful in reducing the occurrence of inappropriate specimens. There has also been a noticeable reduction in the number of telephone enquiries regarding sample volumes although, inevitably, we have had enquiries about the meaning of the strange symbols following test names on the form.

The provision of test menus is, we believe, both useful and essential. The physician can order depending on clinical circumstances, single or profile tests as necessary. There is no compulsion to request

Table 5 Factors to be considered in design of test request form

Layout

Most common tests in centre of form

Clear labelling of sections with logical layout

Stagger lines of request boxes

Maintain basic order once layout optimised

Space available for expansion

Obtain element of consensus from users

Space for

Addressograph label or imprinter

Clinical information

Collection instructions

Collection time

Laboratory receipt and sample number

Instructions to user

Sample tube, blood volume, special containers

Special conditions

Constraints and availability

Special Instructions regarding demanding assays Drug Screening

Therapeutic Drug Monitoring

\section{Laboratory: ward feed-back}

Space for listing request errors or omissions

Revisions

Should be possible and timely

Date of change 


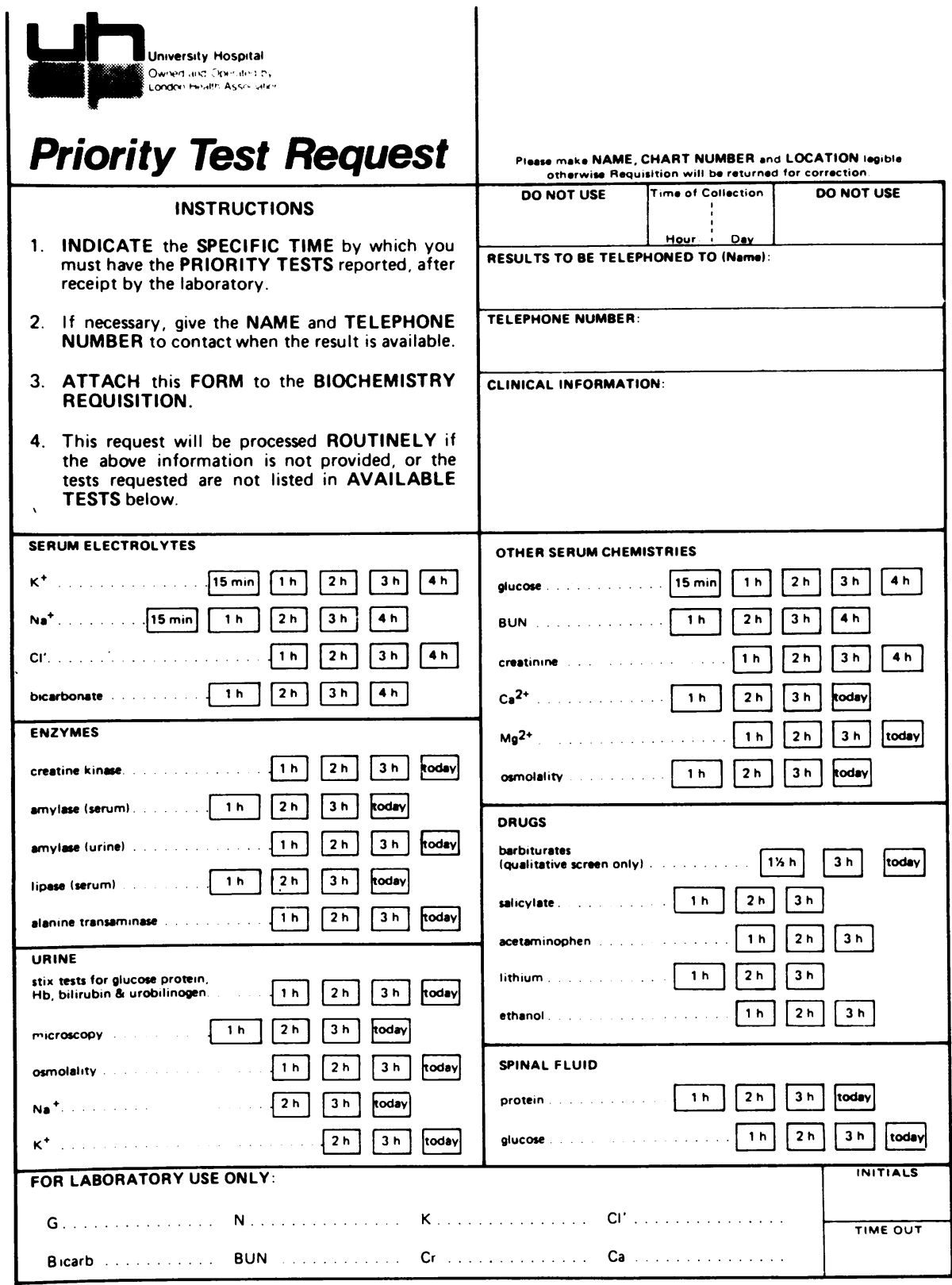

Fig. 5 The revised priority test request form.' The form is printed in red, and measures $28 \times 21.5$ $\mathrm{cm}$. It remains with the specimens in the laboratory, and thus acts as a continual aide-mémoire for the technologist. Results are written on the form as they become available.
12 tests (the SMA II configuration-Table 2) when only a few tests in that grouping are required. For example, a test request for potassium, creatinine, albumin and calcium (parts of the present Admission profile) would be analysed on the SMA II (Fig. 3 ); that is, 12 results would be produced on that sample although the laboratory computer would only record a four-test request and only accept four results. Thus, the physician would only receive results for the four requested tests: the physician's parsimony had an influence on the entire laboratory process-sample receipt, test request entry, work sheet production, result entry and result reporting. Our experience with outpatient requests also indi- 


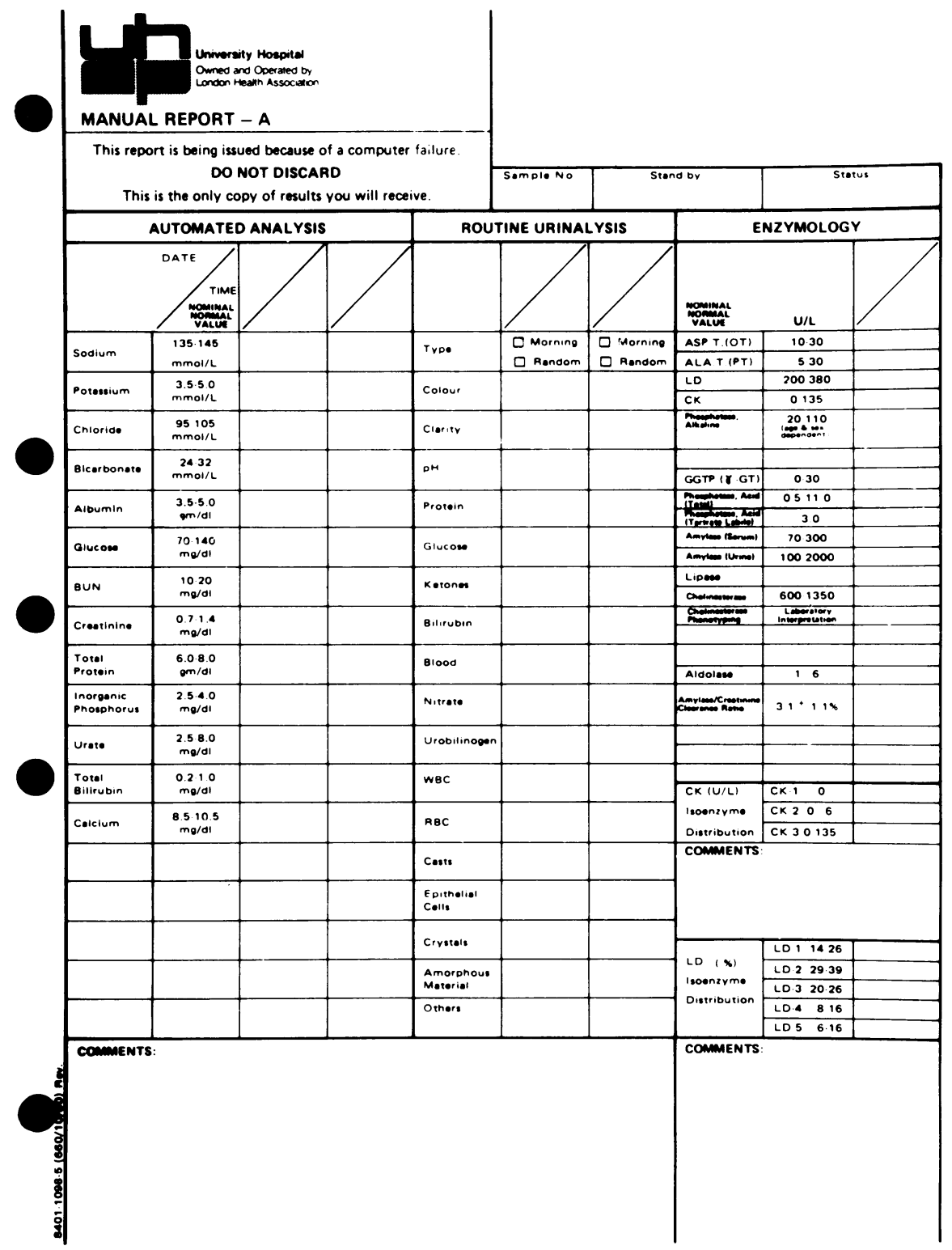

Fig. 6 The back-up form (Manual Report-A) used when the computer reporting system is not available. This report covers the major group of requests. Dimensions are 28 $\times 21.5 \mathrm{~cm}$. 


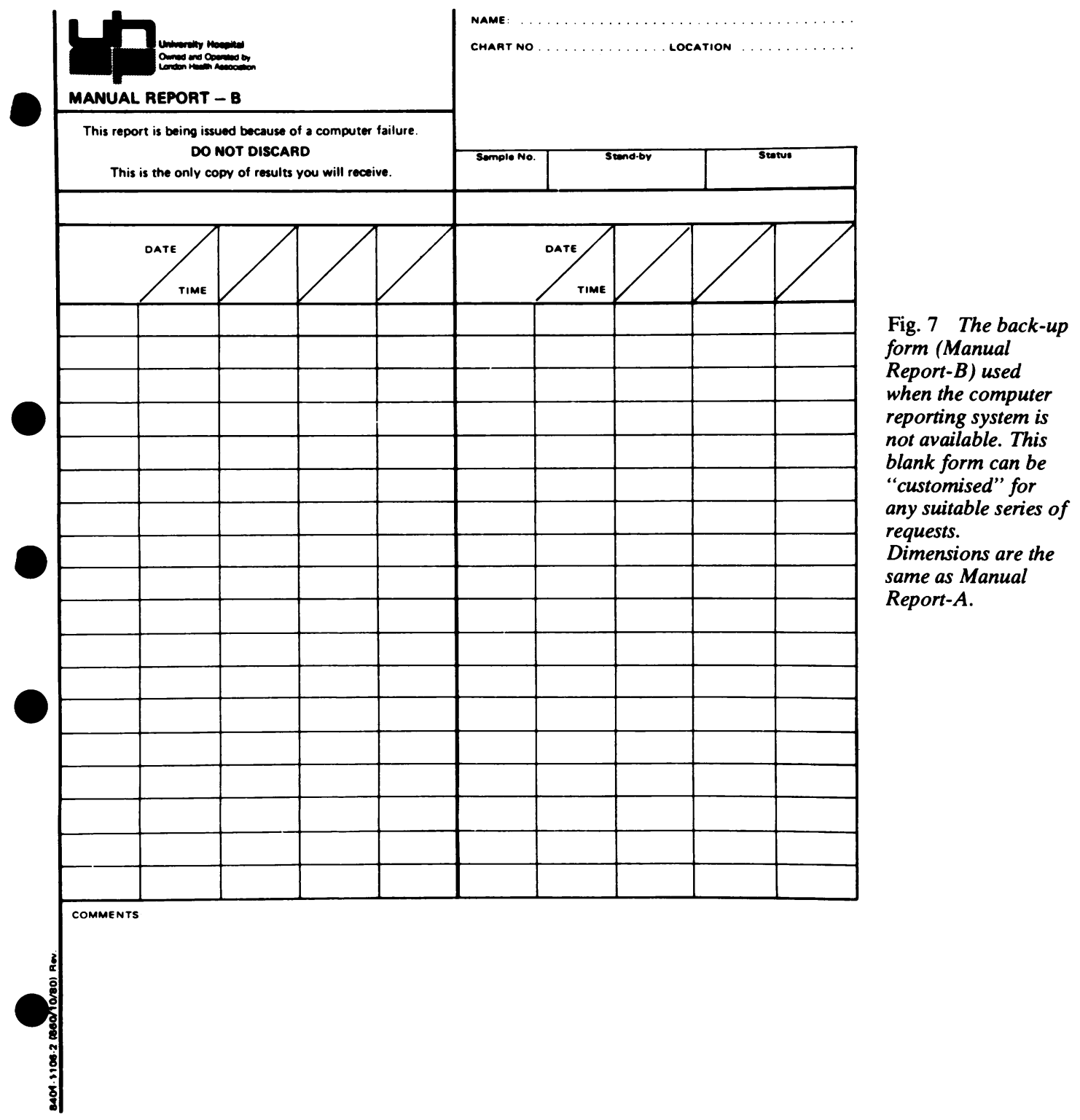

DORIS: There's a lot in the way you pick them up DUSTY: There's an awful lot in the way you feel DORIS: Sometimes they'll tell you nothing at all DUSTY: You've got to know what you want to ask them

DORIS: You've got to know what you want to know

DUSTY: It's no use asking them too much

DORIS: It's no use asking them more than once

DUSTY: Sometimes they're no use at all.
The forms described in this article are the results of many peoples' interest, all of whom I thank. Particular gratitude is due to Mr JF Tuckerman (Chief Technologist of the Department of Clinical Biochemistry) for many useful discussions, Mrs Barbara Jursic for designing, and redesigning, many revisions of these forms, and Mr George Moogk for drawing Fig. 2.

I am grateful for permission to quote lines from 
Sweeney Agonistes, by TS Eliot, granted by Faber \& Faber and Harcourt Brace Jovanovich Inc.

\section{References}

' McLendon WW. Communications and data processing. In: Todd-Sanford-Davidsohn Clinical diagnosis and management by laboratory methods Vol 2, 16th ed. (Henry JB, ed) Philadelphia: Saunders, 1979:2007-32.

${ }^{2}$ NCCLS Tentative Standard: TST/DM-1. Standard for the development of requisition forms for therapeutic drug monitoring and/or overdose toxicology. Villanova: national Committee for Clinical Laboratory Standards, 1980:1-13.

${ }^{3}$ Pippenger CE. Editorial. Ther Drug Monit 1979;1:451-2.

4 Sohn D. The clinician-laboratory connection, the vital link: comments regarding the NCCLS proposed standard for clinical laboratory requisition forms: Ther Drug Monit 1979;1:453-7.

${ }^{5}$ Griffiths WC, Diamon I. Clinical toxicology. In: Race GJ ed. Laboratory medicine Vol 1, (1980 revised edition) Hagerstown: Harper \& Row, 1980: 1-51.

${ }^{6}$ Henderson AR. Use, and abuse, of the telephone in clinical laboratories: a simple solution. J Clin Pathol 1977;30:890-3.

${ }^{7}$ Henderson AR. The priority test request form. A method for improving communication between the physician and the emergency clinical biochemistry laboratory. J Clin Pathol 1979;32:97-9.

${ }^{8}$ Henderson AR, Gardner MD, Griffiths PD, Owen JA, Porter CJ, Tonks DB. Clinical chemistry usage in Britain and Canada. N Engl J Med 1980;303:113-4.

${ }^{9}$ Henderson AR, Gardner MD. Clinical chemistry laboratory productivity: a comparison between a Canadian and a British teaching hospital. J Clin Pathol 1981;34:44-8.

${ }^{10}$ Siegel S. Nonparametic statistics for the behavioral sciences. New York: McGraw-Hill, 1956:95-158.

"World Health Organisation. International classification of disease 9th revision, Clinical Modification, vol 1, Diseases: Tabular List. Ann Arbor: Commission on Professional and Hospital Activities, 1978.

${ }_{12}$ World Health Organisation. International classification of disease 9th revision, Clinical Modification, vol 3, Procedures: Tabular List and Alphabetic Index. Ann Arbor: Commission on Professional and Hospital Activities, 1978.

${ }^{13}$ Burke MD. Clinical problem solving and laboratory investigation: contributions to laboratory medicine. Prog Clin Pathol $1981 ; 8: 1-24$.

${ }^{14}$ Henderson AR. Emergencies and the laboratory. $\mathrm{Br}$ Med $\mathrm{J}$ 1979;ii: 212.

${ }^{15}$ Svirbely JR, Speicher CE. The importance of request and report forms in the interpretation of therapeutic drug monitoring data. Ther Drug Monit 1980;2:211-6.

${ }^{16}$ Walters MI, Speicher CE. Organization of a laboratory service for therapeutic drug monitoring. Clin Lab Med 1981;1:43950.

${ }^{17}$ Grams RR. Medical information systems. Clifton: Humana Press, 1979:80-94.

${ }^{18}$ Eliot TS. Collected poems 1909-1962 London: Faber \& Faber, 1970:123-36

Requests for reprints to: Dr AR Henderson, Department of Clinical Biochemistry, University Hospital, PO Box 5339, Postal Stn. A, London, Ontario, Canada, N6A 5A5. 